\title{
PENGUJIAN KANDUNGAN UNSUR HARA DALAM KOMPOS YANG BERASAL DARI SERASAH \\ TANAMAN JAGUNG MANIS (Zea mays saccharata)
}

\author{
SURTINAH \\ Staf Pengajar Fakultas Pertanian Universitas Lancang Kuning \\ Program Studi Agroteknologi \\ Jl. D.I. Panjaitan Km. 8 Rumbai Telp. (0761)5439
}

\section{ABSTRACT}

This study aims to determine the nutrient content of the compost derived from sweet corn crop residues after harvest. This research is descriptive, wherein the first process is the process of making compost derived from corn crop residue after harvest, are composted for 1 month by using bio activator EM-4. To measure the content of macro nutrients, the test method used is the Kjeldahl method for nitrogen content, while for $\mathrm{P}, \mathrm{K}, \mathrm{CaO}, \mathrm{MgO}$ and $\mathrm{Fe}$ Atomic absortion spectrophotometric used method (AAS), and the content of $C$ - Organic tested by Spectrophotometric method.

Laboratory test results on the compost derived from sweet corn litter containing $\mathrm{N} 1: 05 \%, 1.01 \% \mathrm{P} 2 \mathrm{O} 5,0.18 \% \mathrm{~K} 2 \mathrm{O}, \mathrm{CaO} 1.98 \%, \mathrm{MgO} 0.53 \%, \mathrm{C}-$ $10.5 \%$ Organic, and $C / N$ ratio of 9.97 .

Key Words: Compost, Sweet Corn, $\mathrm{P}, \mathrm{K}, \mathrm{CaO}, \mathrm{MgO}, \mathrm{C}$ - organik, C/N ratio.

\section{PENDAHULUAN}

Kompos merupakan hasil perombakan bahan organik oleh mikroba dengan hasil akhir adalah kompos. Pengomposan merupakan salah satu alternatif pengolahan limbah padat organik yang banyak tersedia disekitar kita. Dari sisi kepentingan lingkungan, pengomposan dapat mengurangi volume sampah dilingkungan kita, karena sebagian besar sampah tersebut adalah sampah organik. Ditinjau dari sisi ekonomi, pengomposan sampah padat organik berarti, bahwa barng yang semula tidak memiliki nilai ekonomis dan bahkan memerlukan biaya yang cukup mahal untuk menanganinya dan sering menimbulkan masalah sosial, ternyata dapat diubah menjadi produk yang bermanfaat dan bernilai ekonomis.

Pengomposan pada dasarnya merupakan upaya mengaktifkan kegiatan mikrobia agar mampu mempercepat proses dekomposisi bahan organik. Yang dimaksud mikrobia adalah bakteri, fungi dan jasad renik, sedangkan bahan organik adalah jerami, sampah kota, limbah 
pertanian, kotoran hewan/ ternak dan sebagainya.

Kebun Percobaan Fakultas Pertanian saat ini digunakan untuk pelaksanaan praktikum mata kuliah Dasar-dasar Agronomi, dengan menanami kebun tersebut dengan tanaman jagung manis. Yang akan menghasilkan sampah pasca panen yang banyak. Bila sampah atau limbah pertanian ini tidak dimanfaatkan secara baik, maka akan menimbulkan tumpukan sampah yang akan merusak kebersihan kampus. Oleh karena itu sisa tanaman pasca panen jagung akan dijadikan kompos. Namun kandungan unsur hara pada kompos sisa tanaman jagung ini belum diketahui dengan pasti, sehingga perlu dilakukan pengujian di Laboratorium. Penelitian ini bertujuan untuk mengetahui kandungan unsur hara pada kompos yang berasal dari sisa tanaman jagung manis pasca panen.

Sampah organik yang berasal dari Kota Buleleng Jagaraga, setelah diolah menjadi kompos kandungan C-organik 29.92\%, dan telah memenuhi standar Permentan no. 28 tahun 2009 yaitu $>12 \%$. Kandungan C-organik merupakan unsur bagi pupuk organik, karena tujuannya adalah untuk meningkatkan kandungan C-organik tanah yang pada umumnya sudah sangat rendah yaitu $2 \%$. Standar kandungan C menurut SNI kompos adalah 9.8\% $32 \%$ (Wahyono,2011).

Kompos yang berasal dari DKI memiliki karakteristik kimia diantaranya C-organik 13\%, N-total $3.53 \%$, P-total $0.53 \%$, K-total 4.44\%, Ca $5.80 \%, \mathrm{Mg} 1.34 \%$ ( Anonim, 2010). Hasil Penelitian Nurhayati ( 2010 ) menginformasikan bahwa hasil analisis sampah pasar yang dikomposkan selama 45 hari memiliki kandungan $\mathrm{N} 1.17 \%$, Corganik $11.46 \%$, P $0.22 \%$, dan K $1.05 \%$. Kompos yang baik mengandung unsur hara makro $\mathrm{N}>$ $1.5 \%, \mathrm{P}_{2} \mathrm{O}_{5}>1 \%$, dan $\mathrm{K}_{2} \mathrm{O}>1.5 \%$, $\mathrm{C} / \mathrm{N}$ ratio antara $15-20$.

Sandrawati, Syofyan,dan Mulyani (2007) melaporkan bahwa terjadi interaksi antara kompos sampah kota dengan pupuk kandang sapi terhadap $\mathrm{pH}$ tanah dan hasil tanaman jagung, secara mandiri 
kompos sampah kota dan pupuk kandang berpengaruh nyata terhadap peningkatan semua parameter uji, hasil terbaik diperoleh pada taraf dosis 15 ton/ha, dimana produksi tanaman meningkat $123 \%$ dari tanaman kontrol.

Widiatmoko

melaporkan bahwa pada dosis 1.25 $\mathrm{kg} / \mathrm{tanaman}$ menghasilkan pertumbuhan diameter batang dan tinggi tanaman nilam lebih tinggi, sedangkan pada dosis kompos sampah kota $0.87 \mathrm{~kg}$ memperlihatkan luas daun dan jumlah daun tanaman nilam yang lebih tinggi. Dan Subagio (2010) melaporkan bahwa pada dosis $250 \mathrm{~g} /$ tanaman pupuk kompos sampah kota pada varitas Talitha menunjukkan hasil yang lebih baik dibandingkan perlakuan yang lain.

Penggunaan kompos sampah

pasar dan pupuk kandang dapat

\section{METODE PENELITIAN}

Penelitian ini merupakan penelitian diskriptif, dimana proses pertama adalah proses pembuatan kompos yang berasal dari sisa tanaman jagung pasca panen, yang meningkatkan pertumbuhan dan produksi tanaman sawi, dan lama pengomposan berpengaruh terhadap kualitas kompos, karena terjadi peningkatan kandungan $\mathrm{N}$ dalam kompos (Nurhayati, 2010). Sedangkan Sutapraja (2008) melaporkan bahwa kedalaman pengolahan tanah $30 \mathrm{~cm}$ dengan dosis kompos sampah kota 15 ton/ha menghasilkan jumlah dan kualitas kubis terbaik.

Marvelia, Sri, dan sarjana ( 2006) melaporkan bahwa rasio $\mathrm{C} / \mathrm{N}$ pada kompos kascing yang tinggi yaitu 35,25\% mengakibatkan pertumbuhan tanaman jagung manis menjadi kurang baik, diduga karena bahan dasar kompos belum terurai sempurna, justru pertumbuhan tanaman jagung manis yang terbaik adalah yang tidak diberi kompos kascing.

dikomposkan selama 1 bulan dengan menggunakan bio aktifator EM-4. Cara pembuatan kompos sebagai berikut: 
a. Serasah jagung manis dicincang halus.

b. Dicampur dengan pupuk kandang dengan perbandingan 3:1 ( 3 bagian serasah jagung : 1 bagian pupuk kandang )

c. Campuran serasah dan pupuk kandang diaduk rata.

d. Selanjutnya disiram dengan larutan EM - 4 dengan konsentrasi $5 \mathrm{ml} /$ air

e. Diaduk lagi, kemudian ditutup plastik.

f. Setiap hari dicek, bila suhu terlalu tinggi maka dilakukan pembalikan.

g. Setelah satu bulan kompos sudah jadi, dan selama proses dekomposisi tidak mengeluarkan bau busuk,

\section{HASIL DAN PEMBAHASAN}

\section{Hasil Penelitian,}

Sampel kompos serasah jagung manis yang diuji di bahkan aroma yang dikeluarkan adalah khas aroma fermentasi.

Kompos yang sudah jadi diambil sampelnya untuk diuji di Labortorium, untuk mengetahui kandungan C-organiknya, dan unsur hara makro maupun unsur mikronya.

Untuk mengukur kandungan unsur hara makro, metode uji yang digunakan adalah metode Kjeldahl untuk kandungan Nitrogen, sedangkan untuk $\mathrm{P}, \mathrm{K}, \mathrm{CaO}, \mathrm{MgO}$ dan $\mathrm{Fe}$ digunakan metode Atomic absortion spectrophometric (AAS), dan Kandungan $\mathrm{C}$ - organik diuji dengan metode Spectrophotometric.

Tabel 1. Hasil Uji Laboratorium Kandungan Unsur Hara dalam Kompos Serasah Jagung Manis.

\begin{tabular}{|l|c|c|c|c|c|c|c|c|c|}
\hline \multicolumn{1}{|c|}{$\mathrm{No}$} & $\begin{array}{c}\mathrm{KA} \\
\%\end{array}$ & $\begin{array}{c}\mathrm{N} \\
\%\end{array}$ & $\begin{array}{c}\mathrm{P}_{2} \mathrm{O}_{5} \\
\%\end{array}$ & $\begin{array}{c}\mathrm{K}_{2} \mathrm{O} \\
\%\end{array}$ & $\begin{array}{c}\mathrm{CaO} \\
\%\end{array}$ & $\begin{array}{c}\mathrm{MgO} \\
\%\end{array}$ & $\begin{array}{c}\mathrm{Fe} \\
\%\end{array}$ & $\begin{array}{c}\mathrm{C} \\
\text { organik }\end{array}$ & $\mathrm{C} / \mathrm{N}$ \\
\hline 1. & 7.20 & 1.05 & 1.01 & 0.18 & 1.98 & 0.53 & 0.19 & 10.5 & 9.97 \\
\hline Metode & \multicolumn{8}{|c|}{ | } \\
\hline
\end{tabular}

(Departement Riset PT. Sarana Inti Pratama, 2012) 


\section{Pembahasan}

Uji Laboratorium

menunjukan bahwa Kompos

Serasah Jagung Manis mengandung beberapa unsur hara makro dan mikro, yang sangat dibutuhkan untuk pertumbuhan tanaman. Sedangkan C organik dari kompos ini tergolong tinggi dan sudah memenuhi syarat untuk pupuk organik. Kandungan COrganik merupakan unsur penting bagi pupuk organik, karena ditujukan untuk menambah bahan organik tanah. Seperti diketahui bahwa kandungan bahan organik tanah di Indonesia pada umumnya dan Riau khususnya sudah berkurang, apalagi Propinsi Riau didominasi oleh tanah podsolik Merah Kuning yang dikenal rendah bahan organik. Saat ini kandungan C-Organik tanah sangat rendah yaitu di bawah $2 \%$, Standar kandungan C-Organik menurut SNI kompos adalah 9.8-32 \% (Wahyono, 2011).

Bambang, Andareas, Nasriati, dan Kiswanto, (2010), menguji unsur hara makro terhadap kompos jerami padi dan jerami jagung, hasil uji memperlihatkan kandungan unsur hara sebagai berikut;

Tabel 2. Kandungan Unsur Hara Kompos yang berasal dari Jerami Padi dan Jerami Jagung.

\begin{tabular}{|l|c|c|c|c|c|}
\hline \multicolumn{1}{|c|}{ Bahan } & C-Organik & $\begin{array}{l}\mathrm{N} \\
\%\end{array}$ & $\begin{array}{l}\mathrm{P} \\
\%\end{array}$ & $\begin{array}{l}\mathrm{K} \\
\%\end{array}$ & $\mathrm{C} / \mathrm{N}$ \\
\hline Jerami Padi & 20.02 & 0.75 & 0.12 & 0.69 & 23.69 \\
\hline Jerami Jagung & 15.91 & 0.67 & 1.05 & 1.18 & 23.75 \\
\hline
\end{tabular}

Nurhayati (2010) melaporkan hasil uji kompos sampah pasar seperti pada Tbel 3 berikut ini.

Tabel 3. Hasil Uji Laboratorium Kompos Pasar yang dikomposkan selama 45 hari.

\begin{tabular}{|c|c|c|c|c|c|}
\hline Bahan & $\mathrm{N}$ & C-Organik & $\mathrm{P}_{2} \mathrm{O}_{5}$ & $\mathrm{~K}_{2} \mathrm{O}$ & $\begin{array}{c}\text { Rasio } \\
\mathrm{C} / \mathrm{N}\end{array}$ \\
\hline Sampah pasar & 1.17 & 11.46 & 0.22 & 1.05 & 9.79 \\
\hline
\end{tabular}

$\mathrm{C} / \mathrm{N}$ rasio yang terkandung di dalam kompos menggambarkan tingkat kematangan dari kompos tersebut, semakin tinggi $\mathrm{C} / \mathrm{N}$ rasio 
berarti kompos belum terurai dengan sempurna atau dengan kata lain belum matang. Pada kompos serasah jagung manis $\mathrm{C} / \mathrm{N}$ rasio 9.97 berarti kompos tersebut telah matang dan sudah memenuhi standar Permentan dan SNI, yaitu kompos dikatakan matang bila rasio $\mathrm{C} / \mathrm{N}$ nya di bawah 20. Murbandono (1992) menyatakan bahwa kompos yang baik adalah kompos yang memiliki $\mathrm{C} / \mathrm{N}$ rasio 10 - 12, sedangkan Novizan ( 2001) menyatakan bahwa kompos yang baik adalah yang mengandung $\mathrm{C} / \mathrm{N}$ rasio $12-15$.

$$
\text { Rasio C/N akan }
$$

mempengaruhi ketersediaan unsur hara, jika $\mathrm{C} / \mathrm{N}$ rasio berbanding terbalik dengan ketersediaan unsur hara, artinya bila $\mathrm{C} / \mathrm{N}$ rasio tinggi maka kandungan unsur hara sedikit tersedia untuk tanaman, sedangkan jika $\mathrm{C} / \mathrm{N}$ rasio rendah maka ketersediaan unsur hara tinggi dan tanaman dapat memenuhi kebutuhan hidupnya.

Tabel 4. Kriteria Penilaian Unsur Hara Tanah

\begin{tabular}{|c|c|c|c|c|c|}
\hline Parameter & $\begin{array}{c}\text { Sangat } \\
\text { rendah }\end{array}$ & Rendah & Sedang & Tinggi & $\begin{array}{c}\text { Sangat } \\
\text { tinggi }\end{array}$ \\
\hline $\mathrm{C}(\%)$ & $<1,00$ & $1,00-2,00$ & $2,01-3,00$ & $3,01-5,00$ & $>5,00$ \\
\hline $\mathrm{N}(\%)$ & $<0,10$ & $0,10-0,20$ & $0,21-0,50$ & $0,51-0,75$ & $>0,75$ \\
\hline $\mathrm{C} / \mathrm{N}$ & $<5$ & $5-10$ & $11-15$ & $16-25$ & $>25$ \\
\hline $\mathrm{P}_{2} \mathrm{O}_{5}(\%)$ & $<0,010$ & $0,01-1,02$ & $0,016-0,025$ & $0,026-0,035$ & $>0,035$ \\
\hline $\mathrm{K}_{2} \mathrm{O}(\%)$ & $<0,010$ & $0,01-0,02$ & $0,021-0,040$ & $0,041-0,060$ & $>0,060$ \\
\hline $\mathrm{Ca}$ me/100g & $<2$ & $2-5$ & $6-10$ & $11-20$ & $>20$ \\
\hline
\end{tabular}

\section{Hasil penelitian kompos} serasah jagung manis bila dibandingkan dengan kriteria pada Tabel 4 di atas dapat dikategorikan baik karena kandungan $\mathrm{C}$ organiknya sangat tinggi, Nitrogennya sangat tinggi, $\mathrm{C} / \mathrm{N}$ rasio rendah, kandungan $\mathrm{P}_{2} \mathrm{O}_{5}$ sangat tinggi, $\mathrm{K}_{2} \mathrm{O}$ sangat tinggi, dan Ca sangat tinggi. Hal ini mmbuktikan bahwa serasah jagung manis dapat dijadikan bahan kompos.

Nitrogen yang terkandung dalam kompos yang berasal dari serasah jagung manis sangat tinggi, hal ini disebabkan karena pada waktu pengomposan dicampur dengan pupuk kandang sapi yang 
mengandung amonia yang tertutupnya stomata dipengaruhi oleh merupakan sumber Nitrogen. keberadaan ion $K$, bila stomata Tersedianya Nitrogen dalam jumlah terbuka berarti proses fisiologi pada yang tinggi karena terjadi proses dekomposisi yang dilakukan oleh mikroorganisme. Nitrogen ini diperoleh melalui tiga (3) tahapan reaksi yaitu; reaksi aminasi, reaksi amonifikasi, dan reaksi nitrifikasi. Reaksi aminasi adalah reaksi penguraian protein yang terdapat pada bahan organik menjadi asam amino; reaksi amonifikasi adalah perubahan asam-asam amino menjadi senyawa-senyawa amonia $\left(\mathrm{NH}_{3}\right)$ dan amonium $\left(\mathrm{NH}_{4}\right)$; dan nitrifikasi adalah perubahan senyawa amonia menjadi Nitrat dengan melibatkan bakteri Nitrosomonas dan Nitrosococus.

Unsur P dibutuhkan tanaman untuk memperkuet perakaran, kekurangan unsur $\mathrm{P}$ perakaran tanaman akan terganggu, selain itu $\mathrm{P}$ juga berperan dalam proses transfer energi, proses fotosintesis, metabolisme dan respirasi (Cholik, 2003).

Unsur Kalium berperan dalam proses asimilasi pada tanaman. Mekanisme terbuka dan tanaman akan berlangsung dengan baik, terutaman proses fiksasi $\mathrm{CO}_{2}$ yang akan menhasilkan asimilat untuk memenuhi kebutuhan hidup tanaman (Surtinah, 2010).

Unsur $\mathrm{Ca}$ berperan dalam sintesa protein yang dibutuhkan untuk pembelahan dan pembesaran sel-sel tanaman, selain berperan dalam menetralkan asam-asam organik yang dihasilkan pada proses metabolisme tanaman, sehingga tanaman terhindar dari keracunan, dan unsur $\mathrm{Ca}$ dapat menaikkan $\mathrm{pH}$. Bila unsur ini berada dalam tubuh tanaman, dengan kenaikan $\mathrm{pH}$ dapat mengaktifkan enzim phofoenolpiruvat karboksilase sehingga akan terjadi perubahan pati menjadi malat yang mengakibatkan air yang berada disekitar sel penjaga masuk ke vakuola yang membuat turgiditas di sel penjaga meningkat dan menyebabkan stomata terbuka, sehingga memudahkan proses asimilasi.

Unsur $\mathrm{Fe}$ dan $\mathrm{Mg}$ yang terdapat dalam kompos serasah 
jagung manis sangat mendukung pada proses pembentukan kloropfil dimana inti dari klorofil adalah $\mathrm{Mg}$, bila Mg tersedia dalam jumlah yang cukup maka pembentukan klorofil akan berjalan dengan baik, bila jumlah klorofil yang dalam organ daun banyak maka proses fotosintesis akan berjalan lancar apabila faktor lingkungan mendukung untuk proses tersebut. Begitu juga dengan $\mathrm{Fe}$, yang merupakan inti dari sitokrom yang berperan dalam proses asimilasi tanaman dalam menhasilkan energi yang digunakan pada proses biokimia tanaman.

\section{KESIMPULAN DAN SARAN}

\section{Kesimpulan}

Kompos dengan

bahan serasah jagung manis mengandung C 10,5 \%, N 1,05\%, $\mathrm{C} / \mathrm{N}$ rasio 9,97, $\mathrm{P}_{2} \mathrm{O}_{5} 1,01 \%, \mathrm{~K}_{2} \mathrm{O}$ $0,18 \%$, dan Ca 1,98 me/100 g

\section{DAFTAR PUSTAKA}

Bambang, W., Andareas, Nasriati, dan Cholik, 2003. Kualitas Unsur Hara makro Kiswanto, $2010 . \quad$ Pembuatan Kompos Jerami Padi dan Jagung. Balai pengkajian Teknologi Pertanian (BPTP) Lampung. Lampung. dijadikan solusi dalam menangani sampah pasca panen jagung manis, dan dapat dikembalikan ke lahan untuk menambah bahan organik ke dalam tanah, sehingga tanah akan dapat menahan air dalam jumlah yang cukup, dan dapat memperkaya mikroba yang bermanfaat dalam mengurai bahan organik tanah, karena bahan organik tersedia untuk diproses menjadi bahan yang siap serap, dan keberadaan mikroba diharapkan dapat menyediakan ketersediaan unsur-unsur yang terjerap dalam koloid tanah menjadi nutrisi bagi pertumbuhan tanaman.

\section{Saran}

Kompos serasah jagung manis ini perlu diuji untuk digunakan dalam budidaya tanaman.
Hasil penelitian ini dapat
Kompos Bahan baku Eceng Gondok (Eichhornia crassippes) Peranannya terhadap Tanaman. Badan Penelitian dan Pengembangan Kota Surabaya. Surabaya. 
Marvelia, A., Sri, D., dan Sarjana, P., 2006. Produksi Tanaman Jagung Manis yang Diperlakukan dengan Kompos Kascing dengan Dosis yang Berbeda. Buletin Anatomi dan Fisiologi, Vol. XIV, No. 2, Oktober 2006.

Murbandono,H. S. I,. 1992. Membuat Kompos. Penebar Swadaya. Jakarta.

Novizan, 2001. Petunjuk Pemupukan yang Efektif. Agromedia Pustaka. Tangerang.

Nurhayati, 2010. Pemanfaatan kompos sampah Pasar untuk Budidaya Sawi Organik. Jurusan Agroteknologi Fakultas Pertanian Universitas Islam Sumatera Utara. Medan.

Sandrawati, A., E., T., Sofyan, O., 2007. Pengaruh Kompos Sampah Kota dan Pupuk Kandang Sapi terhadap Sifat Kimia Tanah dan Hasil Tanaman Jagung Manis pada Fluventic Eutrudepts asal Jatinangor Kabupaten Sumedang. Fakultas pertanian Universitas padjadjaran bandung.
Subagio, V., D., 2010. Pengaruh Pemberian Dosis Pupuk Kompos Sampah Kota terhdap Pertumbuhan dan Hasil 5 Varietas Mawar (Rosa hybrida, sp.). Jurnal Departemen of Agronomy Universitas Muhammadyah Malang. http://studentresearch.umm,ac.id.

Sutapradja, $2008 . \quad$ Pengaruh Kedalaman Pengolahan Tanah dan Penggunaan Kompos Sampah Kota terhadap Pertumbuhan dan Hasil Kubis. J. Hort. 18(1):10-15.

Wahyono, 2011. Kualitas Kompos dan POG dari Sampah Kota Memenuhi Standar Permentan No. 28 tahun 2009.

Widiatmoko, G., 2006. Pengaruh Pemberian Dosis Pupuk Kompos Sampah Kota dan Konsentrasi richodermakoning II terhadap Pertumbuhan dan Hasil Tanaman Nilam. Jurnal Departemen of Agronomy Universitas Muhammadyah Malang. http://studentresearch.umm.ac.id. 
